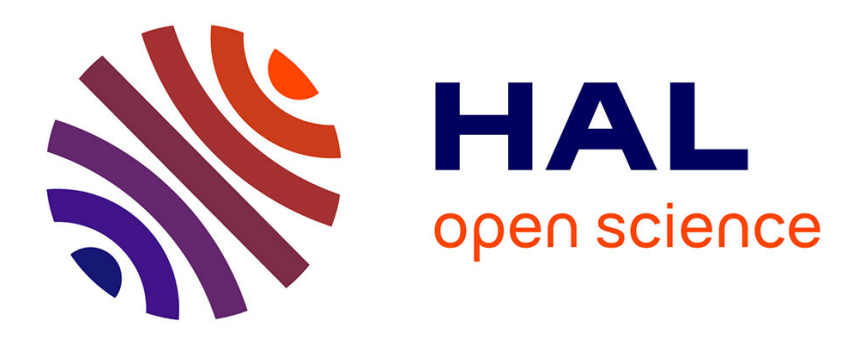

\title{
Research skills training for child psychiatry residents
} Kanita Dervic, Gerhard Lenz, Max H. Friedrich

\section{To cite this version:}

Kanita Dervic, Gerhard Lenz, Max H. Friedrich. Research skills training for child psychiatry residents. European Child and Adolescent Psychiatry, 2009, 19 (5), pp.469-470. 10.1007/s00787-009-0078-8 . hal-00537673

\section{HAL Id: hal-00537673 \\ https://hal.science/hal-00537673}

Submitted on 19 Nov 2010

HAL is a multi-disciplinary open access archive for the deposit and dissemination of scientific research documents, whether they are published or not. The documents may come from teaching and research institutions in France or abroad, or from public or private research centers.
L'archive ouverte pluridisciplinaire HAL, est destinée au dépôt et à la diffusion de documents scientifiques de niveau recherche, publiés ou non, émanant des établissements d'enseignement et de recherche français ou étrangers, des laboratoires publics ou privés. 


\title{
Research skills training for child psychiatry residents
}

\author{
Kanita Dervic · Gerhard Lenz $\cdot$ Max H. Friedrich
}

Received: 23 August 2009/Accepted: 4 November 2009/Published online: 19 November 2009

(C) Springer-Verlag 2009

Early research exposure and mentoring are crucial for later research career [1]. A survey of the US child psychiatrists identified research as one of the training areas which needs improvement [2]. Young child and adult psychiatrists are often ambivalent about which career to pursue, clinical or research one, and this underscores even more the need for obtaining the information and skills during the residency training. In Europe, there is a paucity of the curriculum with regard to acquiring research skills and information on pursuing a research career in both child and adult psychiatry [3, 4]. In this context, we report a new educational initiative at the Department of Child and Adolescent Psychiatry at Medical University of Vienna, Austria.

In the academic year 2007/2008, we started a research skills training for child and adolescent psychiatry residents in order to address current gap in education. The topics covered were, for example, research/academic career planning (i.e. university promotion criteria, career pathways, fellowships abroad), research methods (i.e. study design, basic statistics), and skills acquirement (i.e. writing of a scientific paper, ethics committee applications and grant proposals). The seminars were held throughout the academic year. In total 11 seminars were conducted,

\footnotetext{
K. Dervic $(\bowtie) \cdot$ M. H. Friedrich

Department of Child and Adolescent Psychiatry, University Hospital,

Medical University of Vienna,

Vienna, Austria

e-mail: kanita.dervic@meduniwien.ac.at

G. Lenz

Department of Psychiatry and Psychotherapy, University Hospital, Medical University of Vienna, Vienna, Austria
}

5 during the fall term and 6 during the spring term. Mentoring was offered for each resident to provide an opportunity to start his or her own research under supervision. The frequency of the meetings was arranged between the mentors and mentorees. The mentorees were either involved in an ongoing project of the mentor and were assigned with its specific part, or have had started their own project under supervision. Through these projects, the residents were involved with other research institutions in the country and abroad. One example of the emerged projects is a project in the field of trans-cultural child psychiatry with an international cooperation. Besides the meetings with the mentor, regular and ad hoc meetings as needed were offered through the training director who had a supervising and advisory role. The interaction between training participants was encouraged through the exchange of ideas and experiences between junior and senior residents and, in some cases, through the cooperation on joint projects. Furthermore, interactive discussions with established researchers were organized on how to pursue a research career, and were moderated by the training director.

Our first experience with this pilot project-integrated research skills training for child psychiatry residentsprovides a realistic educational proposal. It could meet the needs of many European countries, which struggle with lack of resources for establishing separate research trainings. The first responses from the residents were positive, and the evaluation of the training, which includes a detailed feedback from the participants, is underway. In 1989, Belmont et al. [5] introduced a somewhat different model of research training for child psychiatric residents in the US, with a 4-month research rotation accompanied by a year of biweekly research meetings. During the research rotation, residents were exposed to a training designed to 
introduce research concepts to them; furthermore, they were assigned to a specific long-term research project in which they applied their interviewing and diagnostic skills, were involved in the development of a psychiatric instrument and contributed to a research grant application. The training encouraged residents' future research activities. Similarly, a substantial increase in research competence and productivity was reported for German internal medicine and psychiatry/psychosomatics/psychotherapy residents who participated in a 1-year intensive clinical research training [6].

In this context, other existing programs in the field of child and adolescent psychiatry should be mentioned like European Research Seminars in Child and Adolescent Psychiatry organized by the European Society for Child and Adolescent Psychiatry (ESCAP) [7]. These seminars are offered for junior researchers in child psychiatry and address a wide range of research issues in the areas of clinical research, treatment evaluation, as well as workshops on how to write and structure a scientific article. Furthermore, the participants have an opportunity to present and discuss their own research conducted in their countries with the supervision of a senior expert. Moreover, Donald J. Cohen Fellowship Award organized by the International Association for Child and Adolescent Psychiatry and Allied Professions (IACAPAP) is another training program for young professionals in the field of child and adolescent psychiatry aiming to foster the professional development of emerging leaders in child and adolescent psychiatry worldwide. This program also includes, among other components, special seminars and mentoring, which is crucial $[8,9]$. Young researchers with the interest in child and adolescent psychiatry from all over the world have an opportunity to participate in these trainings on annual basis. Since our training and these programs share components like seminars and mentoring, the accessability of an in-house research skills training for all residents, however, might be an advantage.
We hope that educational initiatives like the research skills training described in this letter could counteract the current unsatisfactory situation, and encourage child and adolescent psychiatry residents to consider a subsequent research career. It is essential that residents are given an opportunity to assess their interest and capability of pursuing a research and academic career during the residency training.

\section{References}

1. Shapiro T, Mrazek D, Pincus HA (1991) Current status of research activity in American child and adolescent psychiatry: part I. J Am Acad Child Adolesc Psychiatry 30(3):443-448

2. Stubbe DE (2002) Preparation for practice: child and adolescent psychiatry graduates' assessment of training experiences. J Am Acad Child Adolesc Psychiatry 41:131-139

3. Karabekiroglu $K$, Doğangün $B$, Hergüner $S$, von Salis $T$, Rothenberger A (2006) Child and adolescent psychiatry training in Europe: differences and challenges in harmonization. Eur Child Adolesc Psychiatry 15:467-475

4. Lotz-Rambaldi W, Schäfer I, ten Doesschate R, Hohagen F (2008) Specialist training in psychiatry in Europe-results of the UEMSsurvey. Eur Psychiatry 23:157-168

5. Belmont HS, Swift M, Schwartz JL (1989) A model for research training in a child psychiatry residency. Acad Psychiatry 13:159163

6. Löwe B, Hartmann M, Wild B, Nikendei C, Kroenke K, Niehoff D, Henningsen P, Zipfel S, Herzog W (2008) Effectiveness of a 1 -year resident training program in clinical research: a controlled before-and-after study. J Gen Intern Med 23:122-128

7. European Society for Child and Adolescent Psychiatry. http://www.escap-net.org

8. Adler R, Martin A, Park C, Rey J, Tan S (2007) Mentoring young researchers: can the Donald J Cohen Fellowships model be applicable and useful to Australasian psychiatry. Australas Psychiatry 15:232-236

9. Reynolds HY (2008) In choosing a research health career, mentoring is essential. Lung 186:1-6 